\section{Carbohydrates and Postharvest Leaf Blackening of Proteas}

\author{
Iain A. Stephens, Celeste Meyer, Deirdre M. Holcroft, ${ }^{1}$ and \\ Gerard Jacobs \\ Department of Horticultural Science, University of Stellenbosch, Stellenbosch, \\ South Africa 7600
}

Additional index words. glucose, fructose, sucrose, starch, pulsing, proteaceae

\begin{abstract}
Glucose, fructose, sucrose, and starch concentrations were determined in leaves and inflorescences of protea cutflower cultivars soon after harvest and at the onset of leaf blackening while standing in water. At the onset of leaf blackening sugars and starch were lower in both inflorescences and leaves. Proportionately, sugars and starch decreased more in leaves than in inflorescences. Flower-bearing shoots of 'Sylvia' were pulsed individually with $5 \%$ glucose solution until each shoot had taken up $10 \mathrm{~mL}$ solution. Water served for control treatment. Flowers were then stored for 21 days at $1{ }^{\circ} \mathrm{C}$. After pulsing and after cold storage groups of flowering shoots were separated into inflorescence, leaf and stem components and glucose and starch content determined. Glucose content, determined upon completion of pulsing treatments, was significantly greater in all shoot components of shoots pulsed glucose compared with nonpulsed control shoots. Glucose content of leaves was significantly greater after storage for shoots pulsed than control shoots. Starch content of leaves determined upon completion of pulsing treatments was significantly greater in shoots pulsed with glucose than that of controls. There was a significant decrease in starch content for all tissue types during 21 days of storage. Pulsing flower stems of seven protea cultivars before 3 weeks cold storage significantly reduced the incidence of leaf blackening when assessed both on day 1, and again on day 7 after 3 weeks of cold storage. Supplementing holding solutions with $1 \%$ or $2 \%$ glucose reduced leaf blackening of proteas pulsed with glucose and cold stored for 3 weeks.
\end{abstract}

Starch and sucrose have been identified as the main nonstructural metabolic carbohydrates in protea (Bieleski et al., 1992; McConchie and Lang, 1993a, 1993b; McConchie et al., 1991). However, in 'Sylvia' leaves both fructose and glucose were present in higher concentrations than sucrose (Stephens et al., 2001a). Several Protea species produce significant nectar volumes that contain glucose, fructose, sucrose and xylose (Cowling and Mitchell, 1981; Mostert et al., 1980; van Wyk and Nicholson, 1995; Wiens et al., 1983). The nonstructural metabolic carbohydrate concentrations in protea leaves declined rapidly after harvest (Bieleski et al., 1992; McConchie and Lang, 1993a, 1993b; McConchie et al., 1991; Stephens et al., 2001b), particularly at elevated temperatures (Stephens et al., 2001a). The report that $24 \mathrm{~h}$ after the application of ${ }^{14} \mathrm{C}$ sucrose to $P$. neriifolia stems more than $50 \%$ of the radioactivity was found in the nectar (Dai, 1993) supported the hypothesis that carbohydrate depletion in leaves, caused by the demand of the developing inflorescence and nectar production, initiate leaf blackening (Ferreira, 1986; Paull and Dai, 1990). Further support for this notion came from findings that inflorescence removal and girdling significantly reduced or delayed leaf blackening (Brink and de Swardt, 1986; Dai and Paull, 1995; Paull et al., 1980; Reid et al., 1989; Paull and Dai, 1990; Stephens, 2001a; Tranter, 1989). The onset of postharvest leaf

Received for publication 21 May 2004. Accepted for publication 18 July 2004.

${ }^{1}$ Dole Fresh Vegetables, P.O. Box 1759, Salinas, CA 93902. blackening has also been correlated with reduced leaf carbohydrate content (Bieleski et al., 1992; Jones and Clayton-Greene, 1992; McConchie and Lang, 1993b; McConchie et al., 1991, 1994; Newman et al., 1990). Under lighted conditions carbon assimilates and reserves in P. neriifolia shoots were converted to transport carbohydrates during inflorescence development (McConchie et al., 1991).

Carbohydrate supplementation is a recognised practice in storage and vase life extension of many cut flower crops (Goszczyfiska and Rudnicki, 1988; Halevy and Mayak, 1981). Use of exogenous sugars in Protea cut flowers has only been partially successful. Sucrose holding solutions $\left(\sim 2 \mathrm{~g} \cdot \mathrm{L}^{-1}\right)$ have been reported to effectively reduce postharvest leaf blackening of P. compacta (Haasbroek et al., 1973; Ireland et al., 196), P. eximia (Bieleski et al., 1992; Ireland et al., 1967), $P$. cynaroides and $P$. magnifica (Ireland et al., 1967) and P. neriifolia (Brink and de Swardt, 1986; McConchie et al., 1991; Mulder, 1977; Paull and Dai, 1990). Holding solutions with sucrose at higher concentrations exacerbated $P$. neriifolia leaf blackening (Jones, 1991). In contrast, a holding solution with $30 \mathrm{~g} \cdot \mathrm{L}^{-1}$ of sucrose significantly suppressed leaf blackening of P. eximia (Akamine et al., 1979). Sucrose pulsing solutions (200 $\left.\mathrm{g} \cdot \mathrm{L}^{-1}, 24 \mathrm{~h}\right)$ significantly reduced leaf blackening of $P$. cynaroides during long-term dry storage $\left(1{ }^{\circ} \mathrm{C}\right)$ (Jones, 1991). A similar benefit was found in $P$. neriifolia pulsed with sucrose (200 g. $\mathrm{L}^{-1}, 24 \mathrm{~h}, 25^{\circ} \mathrm{C}$ ) before seven days of dark, wet storage at $25{ }^{\circ} \mathrm{C}$ (McConchie and Lang, 1993b). In contrast, sucrose holding solutions did not reduce leaf blackening in protea 'Sylvia' but a $25 \mathrm{~g} \cdot \mathrm{L}^{-1}$ glucose holding solution significantly reduced leaf blackening (Stephens et al., 2001b).

We report on the changes in the concentration of glucose, fructose, sucrose and starch from harvesting flowers until the onset of leaf blackening. Changes in the glucose and starch content caused by pulsing with glucose and after cold storage is reported for protea 'Sylvia. Results on the efficacy of glucose, applied as a pulse or in the holding solution, in reducing leaf blackening is presented for a number of protea cultivars.

\section{Materials and Methods}

Plant material. Flower bearing shoots of 'Brenda' $(P$. compacta $\times P$. burchellii $)$, 'Cardinal' ( $P$. eximia $\times P$. susannae $)$, 'Carnival' $(P$. compacta $\times P$. neriifolia), 'Ivy' (P..lacticolor selection), 'Pink Ice' (P. compacta $\times$ P. susannae), 'Sheila' (P. magnifica $\times$ P. burchellii), 'Susara' (P. magnifica $\times$ P. susannae $)$ and 'Sylvia' $(P$. eximia $\times P$. susannae) were obtained from commercial protea farms near Stellenbosch ( $\left.33^{\circ} 55^{\prime} \mathrm{S} ; 18^{\circ} 50^{\prime} \mathrm{E}\right)$, South Africa. The area has a Mediterranean climate with hot, dry summers and a rainfall of 600 to $700 \mathrm{~mm}$, falling mainly in winter. Shoots were harvested at the soft tip stage and brought to our laboratories within $1 \mathrm{~h}$, or nonpulsed flowers packed for export were collected within $1 \mathrm{~d}$ of delivery from Bergflora, a flower exporting company, at Cape Town International Airport.

Experiment 1: Carbohydrate use. After harvest, the lower leaves were cut off flowerbearing shoots of 'Cardinal', 'Carnival', 'Pink Ice', 'Sheila' and 'Susara' leaving 16 distal leaves. The shoots were divided into two groups for each cultivar. Inflorescences and leaves of one group of stems were processed for freeze-drying soon after harvest, while the other group of stems were placed in water and kept at room temperature $\left(19 \pm 2{ }^{\circ} \mathrm{C}\right)$ and natural light. At the onset of leaf blackening inflorescences and leaves were processed for freeze-drying. Leaves were removed from the stem by cutting and separated into the eight upper and eight lower leaves. Inflorescences were cut in half longitudinally and one-half discarded. Leaves and inflorescences were lyophilised before being milled to a fine powder for carbohydrate analyses. Two flower stems were used per treatment and treatments were replicated five times.

Experiment 2: Glucose supplementation and use. Flower-bearing shoots of 'Sylvia' were pulsed individually with $5 \%$ glucose solution until each shoot had taken up 10 $\mathrm{mL}$ solution (500 mg glucose/shoot). Control treatments were placed in water alone. Treatments were held at $25{ }^{\circ} \mathrm{C}$ under lights (140 $\left.\mu \mathrm{mol} \cdot \mathrm{m}^{-2} \cdot \mathrm{s}^{-1} \mathrm{PAR}\right)$. Upon completion of pulse treatments flowers were packed into polyethylene lined and enclosed SAPPEX S14 fibreboard mini-cartons, and cold stored for 21 $\mathrm{d}$ at $1{ }^{\circ} \mathrm{C}$. After pulsing and after cold storage groups of shoots were separated into flower head, leaf and stem components. Samples were Iyophilized and dry mass determined, before being milled to a fine powder for carbohydrates 
analyses. Twelve single shoot replications per treatment were used. Glucose and starch contents were determined by multiplying the concentration values with the dry weight of the different shoot parts.

Carbohydrate analysis. A 0.5-g sample of the dried tissue described was taken for glucose and starch analysis. Samples were extracted by shaking in 5\% acetic acid for $18 \mathrm{~h}$ and centrifuged $\left(4,000 \mathrm{~g}_{\mathrm{n}}, 10 \mathrm{~min}\right)$. The supernatant was filtered and made up to 100 $\mathrm{mL}$ with $5 \%$ acetic acid. Thereafter, the pellet was resuspended in an acetate buffer $(\mathrm{pH}$ 4.8) and gelatinized in a boiling steam bath for $2 \mathrm{~h}$. The suspension was cooled to $60{ }^{\circ} \mathrm{C}$ and the starch fraction hydrolyzed to glucose with amyloglucosidase (EC 3.2.1.3) (Fluka Chemie, Buchs, Switzerland). Hydrolysis was performed in an incubator maintained at $55^{\circ} \mathrm{C}$ for $18 \mathrm{~h}$. Analysis of glucose, fructose, and sucrose was determined on a Sanplus Segmented Flow Analysis System (method numbers 551965w/rissue 070798/MH and 356-001w/rissue 012998/MH97203066, Skalar, De Breda, The Netherlands). Twelve single shoot replicates per treatment were used.

Experiment 3: Glucose supplementation by pulsing. Flower-bearing shoots of 'Brenda', 'Cardinal', 'Carnival', 'Pink Ice', 'Sheila', 'Susara' and 'Sylvia' were brought to our laboratories. Stems were recut to $50 \mathrm{~cm}$ and the bottom leaves removed leaving on average $25 \pm 5$ leaves per stem. Stems were tagged and placed in buckets containing $1 \mathrm{~L}$ of a glucose solution $(0 \%, 2 \%, 4 \%, 6 \%, 8 \%$, and $10 \%)$. The pulsing solution uptake was monitored until an average $10 \mathrm{~mL}$ was taken up per stem. Pulsing was conducted at $23 \pm 2{ }^{\circ} \mathrm{C}$ under light levels of $300 \mu \mathrm{mol} \cdot \mathrm{m}^{-2} \cdot \mathrm{s}^{-1} \mathrm{PAR}$ supplied by sodium lamps suspended above the flowers. After pulsing, the flowers were randomly packed into cartons, cooled to $4.5^{\circ} \mathrm{C}$ before the lids were closed and kept over night. The next day the cartons were wrapped in polyethylene film and placed in a 12-m integral container for 3 weeks at $1{ }^{\circ} \mathrm{C}$ to simulate sea transport. After cold storage flower stems were recut, randomly placed in buckets with tap water and held at 19 $\pm 2{ }^{\circ} \mathrm{C}$ under natural light. The flowers were evaluated after 1 and $7 \mathrm{~d}$. Ten single shoots were used per treatment except for 'Cardinal', 'Carnival' and 'Susara' where 5, 6, and 8 shoots were used, respectively.

Evaluation of vase life. On each evaluation date leaves with $\geq 5 \%$ of leaf area black or those displaying symptoms of phytotoxicity (leaves that dried out with or without necrotic areas) were removed and counted separately. Leaf blackening was expressed as a percentage leaves with $\geq 5 \%$ leaf area black. Flower quality was assessed subjectively based on general appearance (good, intermediate and poor) and degree of discoloration (phytotoxicity) and wilting of the involucral leaves.

Experiment 4: Post storage glucose supplementation. Flower-bearing shoots of 'Brenda', 'Cardinal', 'Carnival', 'Pink Ice', 'Susara', and 'Sylvia' were prepared for pulsing by recutting shoots to $50 \mathrm{~cm}$ and removal of the lower leaves leaving an average of $25 \pm 5$ leaves per shoot. All cultivars were pulsed, as described earlier, with a $7 \%$ glucose solution, except for 'Brenda' that was pulsed with a $6 \%$ solution, and then cold stored for 3 weeks at $1{ }^{\circ} \mathrm{C}$ as described earlier. After cold storage, stems were recut and the shoots were randomly assigned to buckets with different holding solutions. The holding solutions consisted of water, water with $50 \mathrm{ppm}$ sodium hypochlorite or the latter supplemented with either $1 \%$ or $2 \%$ glucose. Flowers were placed in a controlled temperature room at 19 $\pm 2{ }^{\circ} \mathrm{C}$ and natural light conditions. Flowers were evaluated 1 and $10 \mathrm{~d}$ after removal from storage as described earlier. Ten single shoot replicates ( 8 in the case of 'Brenda') were used per treatment.

Statistical analysis. Analyses of variance (one-way classification) were performed on the data using the SAS program (Statistical Analysis Systems Institute, 1996) and LSD values calculated for the 5\% level of significance. In Experiments 3 and 4 analyses of variance were performed on logit transformed data.

\section{Results}

Experiment 1: Carbohydrate use. At harvest, inflorescences of most cultivars tested contained more glucose or fructose than sucrose (Table 1). In leaves, the concentrations of glucose, fructose and sucrose were comparable except for 'Ivy', which had a higher sucrose level. Glucose and fructose concentrations were consistently higher in inflorescences than in leaves, but for sucrose, the reverse was true. In all cultivars, except for 'Carnival', starch was higher in the leaves than in the inflorescences. At the onset of leaf blackening (Table 1) sugars and starch were lower in both inflorescences and leaves and, in most cases, significantly lower than at harvest for all cultivars tested. Proportionately, sugars and starch decreased more in leaves than in inflorescences.

Experiment 2: Use of supplemented glucose. Glucose content, determined upon completion of pulsing treatments, was significantly greater in all shoot parts of shoots pulsed with $5 \%$ glucose solutions compared with nonpulsed control shoots (Table 2). Glucose content of leaves was a significantly greater for shoots

Table 1. Concentration of glucose, fructose, sucrose, and starch (mg.g ${ }^{-1}$ dry weight) in inflorescences (I) and leaves (L) of proteas 'Cardinal' $(P$. eximia $\times P$. susannae), 'Carnival' (P. compacta $\times$ P. neriifolia), 'Ivy' (P. lacticolor selection), 'Pink Ice' $(P$. compacta $\times$ P. susannae $)$, 'Sheila' $(P$. magnifica $\times$ P. burchellii) and 'Susara' $(P$. magnifica $\times$ P. susannae $)$ flower stems at harvest and at the onset of leaf blackening in a vase.

\begin{tabular}{|c|c|c|c|c|c|c|c|c|c|}
\hline \multirow[b]{2}{*}{ Cultivar } & \multirow{2}{*}{$\begin{array}{c}\text { Plant } \\
\text { part }\end{array}$} & \multicolumn{2}{|c|}{ Glucose } & \multicolumn{2}{|c|}{ Fructose } & \multicolumn{2}{|c|}{ Sucrose } & \multicolumn{2}{|c|}{ Starch } \\
\hline & & Harvest & $\mathrm{H}+\mathrm{x}^{\mathrm{z}}$ days & Harvest & $\overline{\mathrm{H}+\mathrm{x} \text { days }}$ & Harvest & $\mathrm{H}+\mathrm{x}$ days & Harvest & $\mathrm{H}+\mathrm{x}$ days \\
\hline \multirow[t]{2}{*}{ Cardinal } & I & $25.2 \mathrm{a}^{\mathrm{y}}$ & $10.6 \mathrm{~b}$ & $35.1 \mathrm{a}$ & $19.3 \mathrm{~b}$ & $8.1 \mathrm{a}$ & $5.4 \mathrm{a}$ & $5.7 \mathrm{a}$ & $3.1 \mathrm{~b}$ \\
\hline & $\mathrm{L}$ & $12.0 \mathrm{a}$ & $4.2 \mathrm{~b}$ & $10.5 \mathrm{a}$ & $1.5 \mathrm{~b}$ & $13.9 \mathrm{a}$ & $0.9 \mathrm{~b}$ & $20.2 \mathrm{a}$ & $1.7 \mathrm{~b}$ \\
\hline \multirow[t]{2}{*}{ Carnival } & I & $21.5 \mathrm{a}$ & $6.2 \mathrm{~b}$ & $31.5 \mathrm{a}$ & $13.7 \mathrm{~b}$ & $8.7 \mathrm{a}$ & $3.9 \mathrm{~b}$ & $5.4 \mathrm{a}$ & $1.6 \mathrm{~b}$ \\
\hline & $\mathrm{L}$ & $10.5 \mathrm{a}$ & $3.2 \mathrm{~b}$ & $10.9 \mathrm{a}$ & $0.6 \mathrm{~b}$ & $6.9 \mathrm{a}$ & $1.3 \mathrm{~b}$ & $3.5 \mathrm{a}$ & $3.1 \mathrm{a}$ \\
\hline \multirow[t]{2}{*}{ Ivy } & I & $34.2 \mathrm{a}$ & $21.0 \mathrm{~b}$ & $48.6 \mathrm{a}$ & $34.3 \mathrm{~b}$ & $27.6 \mathrm{a}$ & $12.8 \mathrm{~b}$ & $7.6 \mathrm{a}$ & $4.5 \mathrm{~b}$ \\
\hline & $\mathrm{L}$ & $17.9 \mathrm{a}$ & $6.4 \mathrm{~b}$ & $23.5 \mathrm{a}$ & $5.0 \mathrm{~b}$ & $34.1 \mathrm{a}$ & $4.4 \mathrm{~b}$ & $35.4 \mathrm{a}$ & $3.0 \mathrm{~b}$ \\
\hline \multirow[t]{2}{*}{ Pink Ice } & I & $21.2 \mathrm{a}$ & $18.3 \mathrm{~b}$ & $32.5 \mathrm{a}$ & $28.8 \mathrm{~b}$ & $12.5 \mathrm{a}$ & $10.9 \mathrm{a}$ & $4.2 \mathrm{a}$ & $3.2 \mathrm{a}$ \\
\hline & $\mathrm{L}$ & $12.8 \mathrm{a}$ & $4.3 \mathrm{~b}$ & $11.9 \mathrm{a}$ & $2.0 \mathrm{~b}$ & $18.9 \mathrm{a}$ & $2.3 \mathrm{~b}$ & $16.0 \mathrm{a}$ & $3.3 \mathrm{~b}$ \\
\hline \multirow[t]{2}{*}{ Sheila } & $\mathrm{I}$ & $19.1 \mathrm{a}$ & $7.3 \mathrm{~b}$ & $33.1 \mathrm{a}$ & $14.5 \mathrm{~b}$ & $14.0 \mathrm{a}$ & $4.4 \mathrm{~b}$ & $5.2 \mathrm{a}$ & $2.1 \mathrm{~b}$ \\
\hline & $\mathrm{L}$ & $14.0 \mathrm{a}$ & $6.7 \mathrm{~b}$ & $14.4 \mathrm{a}$ & $3.7 \mathrm{~b}$ & $17.0 \mathrm{a}$ & $4.1 \mathrm{~b}$ & $8.5 \mathrm{a}$ & $1.7 \mathrm{~b}$ \\
\hline \multirow[t]{2}{*}{ Susara } & I & $20.7 \mathrm{a}$ & $8.4 \mathrm{~b}$ & $32.1 \mathrm{a}$ & $16.6 \mathrm{~b}$ & $14.3 \mathrm{a}$ & $6.5 \mathrm{~b}$ & $3.3 \mathrm{a}$ & $1.7 \mathrm{~b}$ \\
\hline & $\mathrm{L}$ & $19.6 \mathrm{a}$ & $6.8 \mathrm{~b}$ & $16.0 \mathrm{a}$ & $4.5 \mathrm{~b}$ & $22.5 \mathrm{a}$ & $5.5 \mathrm{~b}$ & $32.2 \mathrm{a}$ & $1.7 \mathrm{~b}$ \\
\hline
\end{tabular}

${ }^{2} \mathrm{x}=$ days to onset of leaf blackening, for 'Cardinal' $\mathrm{x}=4$, 'Carnival', 'Ivy', 'Pink Ice' and 'Sheila' $\mathrm{x}=5$, 'Susara' $\mathrm{x}=7$

${ }^{y}$ Values within cultivar, plant part and carbohydrate group with different subscripts differ significantly at the 5\% level, LSD test.

Table 2. Effect of postharvest pulsing with a $5 \%$ glucose solution (10 mL per stem taken up) on the glucose and starch content of different parts of 'Sylvia' ( $P$. eximia $\times$ P. susannae) flowering shoots, either immediately after pulsing or after cold storage for 3 weeks at $1{ }^{\circ} \mathrm{C}$.

\begin{tabular}{|c|c|c|c|c|c|c|c|c|}
\hline \multirow{3}{*}{$\begin{array}{l}\text { Plant } \\
\text { part }\end{array}$} & \multicolumn{4}{|c|}{ Glucose (mg/shoot part) } & \multicolumn{4}{|c|}{ Starch (mg/shoot part) } \\
\hline & \multicolumn{2}{|c|}{$\begin{array}{c}\text { Immediately } \\
\text { after } \\
\text { pulsing } \\
\end{array}$} & \multicolumn{2}{|c|}{$\begin{array}{l}\text { Pulsed then } \\
\text { cold-stored } \\
\text { for } 3 \text { weeks }\end{array}$} & \multicolumn{2}{|c|}{$\begin{array}{c}\text { Immediately } \\
\text { after } \\
\text { pulsing }\end{array}$} & \multicolumn{2}{|c|}{$\begin{array}{l}\text { Pulsed then } \\
\text { cold-stored } \\
\text { for } 3 \text { weeks }\end{array}$} \\
\hline & Water & $5 \%$ Glucose & Water & $5 \%$ Glucose & Water & $5 \%$ Glucose & Water & $5 \%$ Glucose \\
\hline Inflorescence & $471 b^{z}$ & $566 \mathrm{a}$ & $277 \mathrm{c}$ & $320 \mathrm{c}$ & $130 \mathrm{a}$ & $132 \mathrm{a}$ & $47 \mathrm{~b}$ & $46 \mathrm{~b}$ \\
\hline Leaves & $57 \mathrm{~b}$ & $109 a$ & $11 \mathrm{c}$ & $45 \mathrm{~b}$ & $94 \mathrm{~b}$ & $174 \mathrm{a}$ & $31 \mathrm{c}$ & $40 \mathrm{c}$ \\
\hline Stems & $20 \mathrm{~b}$ & $97 \mathrm{a}$ & $12 \mathrm{c}$ & $17 \mathrm{~b}$ & $12 \mathrm{a}$ & $15 \mathrm{a}$ & $8 \mathrm{~b}$ & $9 \mathrm{~b}$ \\
\hline
\end{tabular}

${ }^{\mathrm{z}}$ Mean separation within plant part and either glucose or starch at the $5 \%$ level, LSD test. 
pulsed with $5 \%$ glucose than nonpulsed control shoots after storage. There was no significant difference in glucose content of inflorescence and stem tissues between pulse treatments after $21 \mathrm{~d}$ of storage. Starch content of leaves determined upon completion of pulsing treatments was significantly greater in shoots pulsed with $5 \%$ glucose solutions than that of nonpulsed controls (Table 2). No significant difference in starch content of inflorescences or stem tissues was found between treatments. There was a significant decrease in starch content for all tissue types during $21 \mathrm{~d}$ of storage. However after $21 \mathrm{~d}$ of storage no significant difference between glucose pulse treatments and controls was found.

Experiment 3: Glucose supplementation by pulsing. Pulsing flowering shoots of 'Brenda', 'Pink Ice', 'Susara', and 'Sylvia' before cold storage significantly reduced the incidence of leaf blackening when assessed both on day 1 , and again on day 7 after 3 weeks cold of storage (Table 3). For 'Brenda' 6\% glucose significantly reduced leaf blackening without phytotoxic effects to the inflorescence, which were evident at $8 \%$ and $10 \%$ glucose pulsing.
Excessive nectar production by inflorescences of 'Pink Ice' negatively affected flower quality in all treatments. The effect of glucose on flower quality could therefore not be determined. Pulsing 'Susara' with glucose in the range of $4 \%$ to $10 \%$ was effective in reducing leaf blackening without being phytotoxic to the flowers. In 'Sylvia', only $8 \%$ glucose reduced leaf blackening and no phytotoxic symptoms were observed at any of the glucose concentrations used. The efficacy of glucose in reducing leaf blackening in 'Cardinal' and 'Carnival' was only evident on day 7 and not $1 \mathrm{~d}$ after cold storage. For both cultivars, glucose in the range of $4 \%$ to $10 \%$ pulses was effective, but $8 \%$ and $10 \%$ were phytotoxic to the flowers of 'Cardinal' but not 'Carnival'. Glucose did not reduce leaf blackening in 'Sheila' and $6 \%$ to $10 \%$ exacerbated leaf blackening and concentrations above $8 \%$ was phytotoxic to the flowers.

Experiment 4: Poststorage glucose supplementation. The incidence of leaf blackening on flower stems of 'Cardinal', 'Carnival', 'Susara' and 'Sylvia' pulsed with glucose before 3 weeks of cold storage were $<9 \%$

Table 3. Effect of a glucose pulse (\%) applied after harvest to flower stems of proteas 'Brenda' (P. compacta $\times$ P. burchellii), 'Cardinal' $(P$. eximia $\times$ P. susannae), 'Carnival' $(P$. compacta $\times$ P. neriifolia $)$, 'Pink Ice' $(P$. compacta $\times$ P. susannae $)$, 'Sheila' $(P$. magnifica $\times$ P. burchellii) and 'Susara' $(P$. magnifica $\times$ $P$. susannae), on the development of leaf blackening (expressed as the percentages of leaves with $\geq 5 \%$ leaf area black), 1 and $7 \mathrm{~d}$ after cold storage for 3 weeks at $1{ }^{\circ} \mathrm{C}$ when held in tap water at ambient conditions.

\begin{tabular}{lccccccr}
\hline & & \multicolumn{7}{c}{ Glucose concn $(\%)$} \\
\cline { 2 - 7 } Cultivar & Days & 0 & 2 & 4 & 6 & 8 & 10 \\
\hline Brenda & 1 & $68 \mathrm{a}$ & $70 \mathrm{a}$ & $26 \mathrm{bc}$ & $9 \mathrm{~d}$ & $17 \mathrm{~cd}$ & $35 \mathrm{~b}$ \\
& 7 & $93 \mathrm{a}$ & $96 \mathrm{a}$ & $66 \mathrm{~b}$ & $31 \mathrm{c}$ & $33 \mathrm{c}$ & $42 \mathrm{c}$ \\
Cardinal & 1 & $17 \mathrm{a}$ & $16 \mathrm{a}$ & $16 \mathrm{a}$ & $2 \mathrm{a}$ & $11 \mathrm{a}$ & $6 \mathrm{a}$ \\
& 7 & $93 \mathrm{a}$ & $53 \mathrm{~b}$ & $22 \mathrm{bc}$ & $12 \mathrm{c}$ & $14 \mathrm{c}$ & $11 \mathrm{c}$ \\
Carnival & 1 & $2 \mathrm{~b}$ & $18 \mathrm{a}$ & $0 \mathrm{~b}$ & $4 \mathrm{~b}$ & $2 \mathrm{~b}$ & $1 \mathrm{~b}$ \\
& 7 & $85 \mathrm{a}$ & $67 \mathrm{a}$ & $3 \mathrm{~b}$ & $12 \mathrm{~b}$ & $8 \mathrm{~b}$ & $11 \mathrm{~b}$ \\
Pink Ice & 1 & $43 \mathrm{a}$ & $14 \mathrm{~b}$ & $11 \mathrm{~b}$ & $0 \mathrm{c}$ & $4 \mathrm{c}$ & $2 \mathrm{c}$ \\
& 7 & $82 \mathrm{a}$ & $41 \mathrm{~b}$ & $35 \mathrm{bc}$ & $16 \mathrm{~cd}$ & $8 \mathrm{~d}$ & $9 \mathrm{~d}$ \\
Sheila & 1 & $19 \mathrm{bc}$ & $12 \mathrm{c}$ & $20 \mathrm{bc}$ & $28 \mathrm{ab}$ & $44 \mathrm{a}$ & $48 \mathrm{a}$ \\
& 7 & $48 \mathrm{c}$ & $38 \mathrm{c}$ & $56 \mathrm{bc}$ & $66 \mathrm{ab}$ & $66 \mathrm{ab}$ & $76 \mathrm{a}$ \\
Susara & 1 & $55 \mathrm{ab}$ & $66 \mathrm{a}$ & $25 \mathrm{bc}$ & $12 \mathrm{c}$ & $16 \mathrm{c}$ & $14 \mathrm{c}$ \\
& 7 & $99 \mathrm{a}$ & $94 \mathrm{a}$ & $52 \mathrm{~b}$ & $41 \mathrm{~b}$ & $48 \mathrm{~b}$ & $52 \mathrm{~b}$ \\
Sylvia & 1 & $25 \mathrm{ab}$ & $39 \mathrm{a}$ & $39 \mathrm{a}$ & $30 \mathrm{ab}$ & $2 \mathrm{c}$ & $13 \mathrm{bc}$ \\
& 7 & $62 \mathrm{ab}$ & $54 \mathrm{ab}$ & $74 \mathrm{a}$ & $55 \mathrm{ab}$ & $28 \mathrm{c}$ & $48 \mathrm{bc}$ \\
\hline
\end{tabular}

${ }^{2}$ Values in the same line with different subscripts differ significantly at the 5\% level, LSD test.

Table 4. Effect of poststorage holding solutions on the development of leaf blackening (expressed as the percentages of leaves with $\geq 5 \%$ leaf area black), after 1 and $10 \mathrm{~d}$ at ambient conditions for proteas 'Brenda' ( $P$. compacta $\times$ P. burchellii), 'Cardinal' ( $P$. eximia $\times$ P. susannae), 'Carnival' $(P$. compacta $\times$ $P$. neriifolia), 'Pink Ice' $(P$. compacta $\times$ P. susannae), 'Sheila' $(P$. magnifica $\times$ P. burchellii $)$, 'Susara' $(P$. magnifica $\times$ P. susannae and 'Sylvia' (P. eximia $\times$ P. susannae). After harvest flower stems were pulsed with $7 \%$ glucose, except Brenda where $6 \%$ glucose was used, and then stored for 3 weeks at $1{ }^{\circ} \mathrm{C}$.

\begin{tabular}{|c|c|c|c|c|c|}
\hline \multirow[b]{3}{*}{ Cultivar } & \multirow[b]{3}{*}{ Days } & \multirow[b]{3}{*}{ Water } & \multicolumn{3}{|c|}{ Hypochlorite (50 ppm) } \\
\hline & & & & \multicolumn{2}{|c|}{ Glucose } \\
\hline & & & & $1 \%$ & $2 \%$ \\
\hline \multirow[t]{2}{*}{ Brenda } & 1 & $19 \mathrm{a}$ & $22 \mathrm{a}$ & $21 \mathrm{a}$ & $24 \mathrm{a}$ \\
\hline & 10 & $57 \mathrm{ab}$ & $67 \mathrm{a}$ & $39 \mathrm{~b}$ & $51 \mathrm{ab}$ \\
\hline \multirow{2}{*}{ Cardinal } & 1 & $4 \mathrm{a}$ & $6 \mathrm{a}$ & $2 \mathrm{a}$ & $5 \mathrm{a}$ \\
\hline & 10 & $94 \mathrm{a}$ & $86 \mathrm{a}$ & $13 \mathrm{~b}$ & $21 \mathrm{~b}$ \\
\hline \multirow[t]{2}{*}{ Carnival } & 1 & $4 \mathrm{a}$ & $3 a$ & $3 a$ & $9 \mathrm{a}$ \\
\hline & 10 & $33 \mathrm{ab}$ & $51 \mathrm{a}$ & $9 \mathrm{~b}$ & $12 \mathrm{~b}$ \\
\hline \multirow[t]{2}{*}{ Pink Ice } & 1 & $11 \mathrm{a}$ & $24 \mathrm{a}$ & $20 \mathrm{a}$ & $17 \mathrm{a}$ \\
\hline & 10 & $17 \mathrm{~b}$ & $66 \mathrm{a}$ & $26 \mathrm{~b}$ & $24 \mathrm{~b}$ \\
\hline \multirow[t]{2}{*}{ Susara } & 1 & $0 \mathrm{ab}$ & $0 \mathrm{a}$ & $1 \mathrm{a}$ & $0 \mathrm{a}$ \\
\hline & 10 & $26 \mathrm{ab}$ & $47 \mathrm{a}$ & $23 \mathrm{~b}$ & $34 \mathrm{ab}$ \\
\hline \multirow[t]{2}{*}{ Sylvia } & 1 & $5 \mathrm{a}$ & $2 \mathrm{a}$ & $2 \mathrm{a}$ & $5 \mathrm{a}$ \\
\hline & 10 & $73 \mathrm{a}$ & $82 \mathrm{a}$ & $25 \mathrm{~b}$ & $20 \mathrm{~b}$ \\
\hline
\end{tabular}

${ }^{\mathrm{z}}$ Values in the same line with different subscripts differ significantly at the 5\% level, LSD test.

on day 1 after cold storage (Table 4). For 'Brenda' and 'Pink Ice' comparable values were about $20 \%$. Compared to water alone, a holding solution of sodium hypochlorite $(50 \mathrm{ppm})$ in water increased leaf blackening after $10 \mathrm{~d}$ in all cultivars tested except for 'Cardinal'. For 'Pink Ice' the increase was significant. Supplementing holding solutions of water and hypochlorite with either $1 \%$ or $2 \%$ glucose reduced leaf blackening compared to water with hypochlorite. Glucose at $2 \%$ was not superior to $1 \%$ and precipitation of glucose on the flower stem did not occur at the lower concentration.

\section{Discussion and Conclusions}

Energy requirements by the leaves and mobilization of sucrose from the leaf to the inflorescence a phenomenon demonstrated by Dai (1993) with radioactive sucrose are possible reason for the depletion of leaf starch, glucose and fructose to low levels (Tables 1 and 2). Glucose, fructose and sucrose concentrations in inflorescences did not decline to the same low levels as in leaves. This could possibly be attributed to the secretion of some of the sugars as well as part of the starch-derived glucose in inflorescences in the form of nectar.

The significant increase in leaf, but not in stem and inflorescence starch content of shoots pulsed with $5 \%$ glucose solutions when determined directly postpulsing formed an important source of glucose during the cold storage period. This is evident by the result that, after 3 weeks of cold storage, the leaf glucose content of $45 \mathrm{mg}$ was comparable to the $50 \mathrm{mg}$ glucose of nonglucose pulsed shoots before cold storage as compared to the $11 \mathrm{mg}$ after cold storage. Apart from the increase in leaf glucose and starch that were available to meet leaf requirements, part of the $77 \mathrm{mg}$ glucose taken up by the stem could slowly have been transported into the leaves as leaves transpire slowly during cold storage. This could explain the effectiveness of glucose applied as a pulse (Table 3 ) or in holding solutions (Table 4) in reducing leaf blackening. Several phenolic compounds are found in the Proteaceae (Elsworth and Martin, 1971; Perold, 1993; Perold and Carlton, 1989; Perold et al., 1973a, 1973b, 1979; van Rheede van Oudtshoom, 1963). In leaves of Protea species susceptible to leaf blackening unstable O-glycoside esters, formed from 3-D-sugars such as glucose and allose, and aglycones, typically di- and trihydroxybenzene derivatives have been identified (Perold, 1993; Perold and Carlton, 1989; Perold et al., 1973a, 1973b, 1979). In contrast, the nonblackening Proteaceae members contain stable C-glycoside esters (Elsworth and Martin, 1971; Perold, 1993). Phenolic glycoside esters hydrolysed by glycosidase enzymes result in a free sugar and a reactive phenolic moiety (Dey and Dixon, 1985), which can undergo nonenzymatic oxidation resulting in leaf blackening. McConchie et al. (1994) suggested that glycosalated compounds may be cleaved under periods of carbohydrate stress. It is therefore possible that high glucose levels in protea leaves may 
limit hydrolysis of phenolic glycoside esters and, therefore, leaf blackening.

Glucose, either as a pulses treatment or as a supplement to holding solutions, effectively reduced the incidence of postharvest leaf blackening in 'Brenda' $(P$. compacta $\times P$. burchellii), 'Cardinal' $(P$. eximia $\times P$. susannae), 'Carnival' (P. compacta $\times$ P. neriifolia), 'Pink Ice' (P. compacta $\times P$. susannae $)$, 'Susara' (P. magnifica $\times$ P. susannae), and 'Sylvia' (P. eximia $\times P$. susannae) (Tables 3 and 4, Stephens, 2003) as well as in 'White Pride' ( $P$. longifolia selection), 'Lady Di' (P. magnifica $\times P$. compacta $)$, and 'Candida' ( $P$. magnifica $\times$ P. obtusifolia) (Jacobs, unpublished data). In contrast, glucose had little or no effect on postharvest leaf blackening of $P$. magnifica, $P$. grandiceps, $P$. cynaroides, 'Ivy' (P. lacticolor selection) Stephens (2003), and Venus (P. repens $\times$ P. aristata) (Jacobs, unpublished data). Proteas can therefore be classified as those cultivars and species responsive and those not responsive to glucose. Superficially it appears that species belonging to the section Ligulatae (Rebello, 2001) of the genus Protea or in the case of hybrids if one parent belong to this section then glucose is effective in reducing postharvest leaf blackening.

Hypochlorite increased leaf blackening and should not be used as a preservative. (Table 4) Since carbohydrates are depleted more rapidly at elevated temperatures (Stephens et al., 2001a) glucose supplementation of holding solutions for proteas after cold storage, in addition to a glucose pulse treatment before cold storage, is recommended to reduce the development of leaf blackening.

\section{Literature Cited}

Akamine, E.K., T. Goo, and R. Suehisa. 1979. Relationship between leaf darkening and chemical composition of leaves of Protea. Flor. Rev. 163:62-63,107-108.

Bieleski, R.L., J. Ripperda, J.P. Newman, and M.S. Reid. 1992. Carbohydrate changes and leaf blackening in cut flower stems of Protea eximia. J. Amer. Soc. Hort. Sci. 117:124-127.

Brink, J.A. and G.H. de Swardt. 1986. The effect of sucrose in vase solution on leaf browning of Protea neriifolia R. Br. Acta Hort. 185:111-119.

Cowling, R.M. and D.T. Mitchell. 1981. Sugar composition, total nitrogen and accumulation of $\mathrm{C}^{14}$ assimilates in floral nectaries of Protea species. J. S. Afr. Bot. 47:743-750.

Dai, J-W. 1993. Postharvest leaf blackening in Protea neriifolia R. Br. PhD diss. Univ. Hawaii at Manoa, Honolulu.
Dai, J-W. and R.E. Paull. 1995. Source-sink relationship and Protea postharvest leaf blackening. J. Amer. Soc. Hort. Sci. 120:475-480.

Dey, P.M. and R.A. Dixon. 1985. Glycosides, p. 131-148. In: P.M. Dey and R.A. Dixon (eds.). Biochemistry of storage carbohydrates in green plants. Academic Press, New York.

Elsworth, J.F. and K.R. Martin. 1971. Flavonoids of the Proteaceae. Part I. A chemical contribution to studies on the evolutionary relationships in the South African Proteoideae. J. S. Afr. Bot. 37:199-212.

Ferreira, D.I. 1986. The influence of temperature on the respiration rate and browning of Protea neriifolia R. Br. inflorescences. Acta Hort. 185:121-129.

Goszczyfiska, D.M. and R.M. Rudnicki. 1988. Storage of cut flowers. Hort. Rev. 10:35-62.

Haasbroek, F.J., G.G. Rousseau, and J.P. de Villiers. 1973. Effect gamma-rays on cut blooms of Protea compacta $\mathrm{R}$. Br., P. longiflora Lamarck and Leucospermum cordifolium Salisb. ex Knight. Agroplantae 5:33-42.

Halevy, A.H. and S. Mayak 1981. Senescence and postharvest physiology of cut flowers. Part 2. Hort. Rev. 3:59-143.

Ireland, J.P., J.T. Meynhardt, and J.M. Strauss. 1967. When proteas become sailors: Treatment before shipping. Farming in S. Afr. 43:33-35.

Jones, R.B. 1991. Understanding and controlling leaf blackening in Protea leaves: The use of high concentrations of sucrose, p. 313-322. Proc. Intl. Protea Assn. 61 Biennial Conf., Perth, Western Australia.

Jones, R.B. and K.A. Clayton-Greene. 1992. The role of photosynthesis and oxidative reactions in leaf blackening of Protea neriifolia $\mathrm{R}$. Br. leaves. Scientia Hort. 50:137-145.

McConchie, R., N.S. Lang, and K.C. Gross. 1991. Carbohydrate depletion and leaf blackening in Protea neriifolia. J. Amer. Soc. Hort. Sci. 116:1019-1024.

McConchie, R. and N.S. Lang. 1993a. Postharvest leaf blackening and preharvest carbohydrate status in three Protea species. HortScience 28:313-316

McConchie, R. and N.S. Lang. 1993b. Carbohydrate metabolism and possible mechanisms of leaf blackening in Protea neriifolia under dark postharvest conditions. J. Amer. Soc. Hort. Sci. 118:355-361.

McConchie, R., N.S. Lang, A.R. Lax, and G.A. Lang. 1994. Reexamining polyphenol oxidase, peroxidase, and leaf blackening in Protea. J. Amer. Soc. Hort. Sci. 119:1248-1254.

Mostert, D.P., W.F. Siegfried, and G.N. Louw. 1980. Protea nectar and satellite fauna in relation to the food requirements and pollinating role of the cape sugarbird. S. Afr. J. Sci. 76:409-412.

Mulder,P.W.A. 1977. Primere meganismes betrokke by die bruinwording van lootblare in Protea neriifolia. MSc thesis. Randse Afrikaans Univ. Johannesburg, South Africa.
Newman, J.P., W. van Doorn, and M.S. Reid. 1990. Carbohydrate stress causes leaf blackening in Proteas. Acta Hort. 264:103-108.

Paull, R.E., T. Goo, R.A. Criley, and P.E. Parvin. 1980. Leaf blackening in cut Protea eximia: importance of water relations. Acta Hort. 113:159-166.

Paull, R.E. and J-W. Dai. 1990. Protea postharvest black leaf a problem in search of a solution. Acta Hort. 264:93-101.

Perold, G.W. 1993. Consistency and variation in metabolite patterns of South African Proteaceae: A chemical perspective. S. Afr. J. Sci. 89:90-93.

Perold, G.W., P. Beylis, and A.S. Howard. 1973a. Metabolites of Proteaceae. Part VII.Lacticolorin, a phenolic glucoside ester and other metabolites of P. lacticolor Salisb. J. Chem. Soc. Perkin Trans. 11973:638-642.

Perold, G.W., P. Beylis, and A.S. Howard. 1973b. Metabolites of Proteaceae. Part VIII. The occurrence of (+)-D-allose in nature: Rubropilosin and pilorubrosin from Protea rubropilosa Beard. J. Chem. Soc. Perkin Trans. 1973:643-649.

Perold, G.W., M.E.K. Rosenburg, A.S. Howard, and P.A. Huddle. 1979. Metabolites of Proteaceae. Part 9. Eximin (6-0-benzoylarbutin) and the synthesis of aryl glycoside esters. J. Chem. Soc. Perkin Trans. I 1979:239-243.

Perold, G.W. and L. Carlton. 1989. Neriifolin, an ester glucoside of benzene-1,2,4-triol. J. Chem. Soc. Perkin Trans. 1 1989:1215-1217.

Rebello, A.G. 2001. Proteas a field guide to the proteas of Southern Africa. Fernwood Press, Vlaeberg, S. Afr.

Reid, M.S., W.G. van Doom, and J.P. Newman. 1989. Leaf blackening in proteas. Acta Hort 261:81-84.

Stephens, I.A., D. M. Holcroft, and G. Jacobs. 2001a Low temperatures and girdling extend vase life of 'Sylvia' Proteas. Acta Hort. 545:205-214.

Stephens, I.A., G. Jacobs, and D.M. Holcroft. 2001b. Glucose prevents leaf blackening in 'Sylvia' proteas. Postharv. Biol. Technol. 23:237-240.

Stephens I.A., D.M. Holcroft, and G. Jacobs. 2003. Storage and vase life extension of 'Sylvia' protea flowers. Acta Hort. 600(1):123-126

Tranter, D. 1989. Postharvest blackleaf in the Protea cultivar 'Pink Ice'. J. Intl. Protea Assn. 17:13-20.

Van Rheede van Oudtshoom, M.C.B. 1963. Distribution of phenolic compounds in some South African Proteaceae: A contribution to the chemotaxonomy of the family. Planta Med. 4:399-406.

Van Wyk, B-E and S.W. Nicholson. 1995. Xylose is a major nectar sugar in Protea and Faurea. J. S. Afr. Sci. 91:151-152.

Wiens, D.,J.P. Rourke, B.B. Casper, E.A. Rickart, T.R. LaPine, C.J. Peterson, and A. Channing. 1983. Nonflying mammal pollination of southern African proteas: a noncoevolved system. Ann. Mo. Bot. Gard. 70:1-31. 